\title{
Hääle semiootilised funktsioonid Siberi rahvaste folklooris ja uskumustes
}

Jelena Novik

Folkloori seisukohalt olulised mitteverbaalsed väljendusvahendid (miimika, žestid, intonatsioon) on alahinnatud (Tšistov 1975: 36). Häälel kui inimese märgilise käitumise instrumendil on nende seas eriline koht.

Artiklis on püütud süstematiseerida Siberi suulistes traditsioonides esinevaid ettekujutusi häälest, välja tuua selle semiootilised funktsioonid ja jälgida nende moondumist mõningate arhailise folkloori eripärade tõttu. Esmalt peatun loodushäälte interpretatsioonidel, seejärel vaatlen ettekujutusi, mis on seotud inimese hääle ja mütoloogiliste tegelaste "häälega", ja lõpuks analüüsin hääle kasutamise vorme jutustavates folklooritekstides.

Siberi pärimus liigitub arhailise folkloori hulka ja on läbinisti suuline kultuur. On loomulik, et akustiline kanal on nendes tingimustes maksimaalselt koormatud ja loodushäältele pööratakse kõrgendatud tähelepanu. E. Kreinovitš on avastanud, et nivhi keeles eristatakse sufiksite abil kolme kvantitatiivselt gradatiivset heliliiki: ühekordne heli, heli, mida kestvalt ja ühtemoodi teeb üks olend ja helid, mida teevad paljud elusolendid. Olin hämmeldunud, kirjutas uurija, et nivhid eristavad loodushääli nii peenelt. Nendega suhtlemisel tundus kogu ümbruskond olevat täidetud helidega, mida ma senini ei olnud märganud ega kuulnud (Kreinovitš 1973: 106-107).

Loomade karjed, puu kägin, putukate sirin jne identifitseeriti intensiivselt, mis viis looduslikele helidele märgilise tähenduse andmiseni. Selle tulemusena ei hinnatud neid informatiivses mõttes müra, vaid häältena, millest igaühe taga on kindel olend. Kõla oli tihti üks võimalikke, aga mõnikord ainuke tõend fü̈̈siliste objektide ja kujutlusvõime viljade reaalsusest (Sagalajev \& Oktjabrskaja 1990: 143). Selline kõlaline realiteet ja helide olulisus suulise kultuuri kandjatele väljendub hästi šori kõnekäänus "Mida kõrvad kuulevad, seda näeb silmgi” (Sagalajev \& Oktjabrskaja 1990: 143). 


\section{Jelena Novik}

Vaatlen kõigepealt erinevate helide interpreteerimist akustiliste signaalidena.

Paljude akustilisel koodil põhinevate uskumuste, ennete ja ennustuste hulgas on enimtuntud "tule keelega" seotud kompleks. Eveenidel oli näiteks terve "sõnastik", millele alusel interpreteeriti süte praksumist tuleasemel. Kui see vaikselt kustus, arvati, et ta nukrutseb, kui põles eredalt - rõõmustab. Kui põleb ebaühtlaselt - pahandab, kui praksub ja tossab, siis vihastab. Kõik hoiatuse ja kaitsmisega seotud eveenikeelsed mõisted on sõnaga tuli (tog) samatüvelised (Popova 1981: 186).

Nende näidete varal on selge, et heli, mida interpreteeritakse, võetakse vastu kui omamoodi žest selle sõna interaktsioonilises tähenduses, ${ }^{1}$ s.t heli tekitava isiku kavatsusena anda edasi mingit informatsiooni või põhjustada vastureaktsiooni.

Enamgi veel, vahel luuakse interpretatsioon küsimuse-vastuse mudeli põhjal: kui inimese mõttele vastuseks kuuldus tulest ükskaks kõlavat heli, pidi see tähendama hoiatust, tugev järsk praksatus oli erilise ohu märk, vaikne heli ja suur säde tähendas jahi heakskiitmist ja käsku minna sädeme lendamise suunas (Popova 1981: 186). Sellise dialoogi reduktsiooniks on ended ja ennustused. Näiteks negidaalid arvasid, et kui lõkkest kostab praksatus, mis sarnaneb lasule, tuleb jaht edukas, kui aga praksatus sarnaneb karjele, on parem sel päeval jahile üldse mitte minna, niikuinii kedagi ei tapa (Tsintsius 1971: 185-186). Selliseid näiteid on üsna palju.

Võib väita, et ettekujutus tule "keelest" põhineb tulejumaluse või -haldja kultusel. Kuid nagu järgnevalt näeme, on helide interpreteerimisel põhinevad ended ja ennustused sageli seotud selliste objektidega, mille puhul pole põhjust rääkida kultusest ega austusest. Seetõttu tekib oletus, et animistlik maailmatunnetus on paljuski suuliste kultuuride semiootilise mehhanismi tagajärjeks (mitte põhjuseks), mille mõjul interpreteeritakse kogu saadud informatsiooni kui kindla isiku edastatut.

Akustilistel signaalidel põhinevate ennete ring on Siberi suulise kultuuriga rahvastel väga lai: pajaraua rõngaste heli tähistas külalise saabumist, erinevate lindude häälitsemisel põhinesid paljud ilmaennustused, öised helid, nagu näugumine ja öökulli huiked, mida identifitseeriti kurja vaimu häälena, ennustasid halba jne. Koduloomad, aga ka tuli võisid hoiatada pererahvast ähvardavast ohust: jakuutidel võis inimene saada teada kurja vaimu (abaasõ) 
lähenemisest elupaigale laudas olevate lehmade erilise nohina järgi või koerte ja vasikate aevastustest. Saanud sellise hoiatuse, võttis inimene tarvitusele vajalikud ettevaatusabinõud: nt sülitas kolm korda üle vasaku õla ja lõi liiga lähedale tulnud vaimu lahtise peoga.

Eksisteerisid ka puhtalt akustilised tõrjetegevused: et kurjad vaimud (abaasõ) majast välja saada, pidi toas tulistama magajaid ette hoiatamat, nii et kõik, sh ka kuri vaim, ehmuksid (Popov 1949: 263). Püüdena ära ajada kurja vaimu käsitleti ka eriliste koerte käitumist, kes tundsid isegi jurtas olles kurja vaimu lähenemist — nad mhakkasid tigedalt haukuma ja ajasid ta niiviisi minema (Popov 1949: 263). Selliseid, nn nelja silmaga ${ }^{2}$ - heledate laikudega kulmude kohal - koeri peeti šamaan-koerteks, kes kaitsesid peremehi. Tõrjevahenditeks kasutati ka muusikariistu (eriline käsitrumm-amulett õmõõ ja parmupill); arvati, et kurjadele vaimudele meeldib väga parmupilli hääl, kuid püüdes sellele järgneda, eksivad nad varsti ja lähevad löödult minema (Popov 1949: 265).

Jakuudid ennustasid helide põhjal (tanha ehk 'kuulatamine'). Kaks, neli või kuus inimest lähevad välja, istuvad jääaugu äärde ja kuulavad: kui kellelgi tuleb surra, kuulevad nad ohkeid ja nuttu, kui keegi tapab järgmisel jahil looma - selle looma samme, kui sünnib laps, on kuulda lapse nuttu või linnu laulu, kui sigivad hobused - hobuse hirnumist, kui poegivad lehmad - lehma ammumist, kui tüdruk peab mehele minema, siis kabjaplaginat (Hudjakov 1969: 398).

Sari endeid ja uskumusi põhineb loomahäälte interpreteerimisel nende kõnena. Näiteks kui härg öösel laudas ammub, tähendab see, et ta küsib viljakusjumalanna Aiõõsõtilt karja (Popov 1949: 293); hundid tõstavad enne saaklooma murdmist pea üles ja uluvad - küsivad taevalt luba ja tapavad saagi loa saanult (Popov 1949: 287). Fonoleksikaalsete kompleksidega sarnaselt on üles ehitatud ka mõningad ended: kui rästas karjub tšark-tšark, samõõr tus! ('saja, vihmake!'), lähebki vihmale (Hudjakov 1969: 49). Ainudel tähendab luige karje tši-no, tši-no, tši-no soseivaje ('prae hästi ja söö') edukat jahti, aga tši-no, tši-no, tšhi-no tšino fuvaje ('ole valmis sööma toorelt') ebaõnne.

Nagu näha, seletatakse nii heli, selle akustilist iseloomu kui ka tema mõjuefekti. Helidele omistatakse aktiivselt tähendusi, käsitletakse neid kui hoiatust või heakskiitu jne. Nad täidavad ennustuste rolli, mis omakorda võivad muutuda enneteks või uskumusteks. Aga see või teine akustiline detail võib saada süžeeliselt organiseeritud teksti või selle fragmendi tuumaks. 
Juba toodud näidetest selgub, et looduse helidesse suhtumise süsteemi kese on kuulaja ja tema interpretatsioonid, s.t tegemist on loomuliku keele süsteemile vastupidise situatsiooniga, mille puhul kõik kategooriad on orienteeritud kõnelejale. Muide, need interpretatsioonid on tavaliselt piiratud elutähtsate küsimustega, millele peab vastama, et saadud informatsiooni adekvaatselt mõista, ja nimelt: kelle teade, mis ta selle all silmas pidas ja miks (mis eesmärgil) ta selle saatis?

Teine laialt levinud akustiliste märkide liik on loodushäälendid. Nendes annab inimene teate, maskeerides ennast loodushääli imiteerides.

Sporaadilisi loodushäälendeid kasutatakse ka olendite märkimiseks. Nii näiteks on nivhi keeles kajaka, nepi, luige, hane, käo, öökulli nimi nende häälitsuste jäljendus (Kreinovitš 1973: 105). Samasuguse tähelepaneku tegi 19. sajandi alguses obiugrilaste juures F. Beljavski. Kirjeldades lindude püüdmist võrkudega, pani ta tähele, et inimesed, kes istuvad võrgu juures, meelitavad hanesid, jäljendades täpselt nende häälitsemist. Märgime seejuures, et iga seitsmest Siberis tuntud haneliigist häälitseb ja lendab isesuguselt ning meistrid eristavad neid juba kaugelt lennu järgi ja tekitavad vilega imetlusväärse täpsusega vastavaid helisid, meelitades sel viisil linde pü̈̈gikohale (Kossarev 1984: 93). Siin kasutatakse häälte jäljendamist nii liikide eristamisel (lindude äratundmine häälitsuste järgi koos visuaalse informatsiooniga nende lennust) kui ka ligimeelitamisel. Ja kui keele formeerimisel on helijäljenduste osa nähtuste tähistamisel suhteliselt väike (põhirolli mängib siin motiveerimata konventsionaalne keeleline sümbol), siis mitteverbaalses helilises kommunikatsioonis mängivad need üsna olulist rolli, olles üheks vahendiks, millega juhitakse imiteeritavate käitumist.

Jahinduses kasutatakse laialdaselt hääle või peibutusvilega tekitatud loodushäälendeid (invokatsiooni) looma kutsumiseks. J. Kreinovitši (1973) tähelepanekute kohaselt teavad nivhi jahimehed, mil viisil on võimalik äratada hüljeste uudishimu ja neid ligi meelitada: noort sivutšit peibutatakse häälitsusega urururu, suurt häälega $u$ $u$, mida hääldatakse läbi nina; üht teatud liiki väikest hüljest aga madala möirgava karjega gap, aga teise liigi looma karjega $p u, p u$ (võib karjuda ka po, sest nad on rumalad ja kuulavad niikuinii). Peale selle vilistatakse vana hüljest uudishimu äratamiseks, või lüüakse käe või aeruga vastu paadiäärt, kui hüljes on noorem. Alguses noor hüljes sukeldub, kuid seejärel pistab uudishimust pea veest välja, mida aga jahimees ootabki (Kreinovitš 1973: 148). 
Viimase näite põhjal on hästi näha, et jahiobjekti hinnatakse kui subjekti, enamgi veel, kui suhtluspartnerit: jahimees arvestab looma käitumismaneeridega ja provotseerib looma käituma endale kasulikult. Helilised "maskeeringud" teenivad sama eesmärki: näiteks emaspõhjapõdra häält imiteerides saavutab jahimees selle, et talle läheneb just nimelt isane loom.

Nagu kirjutab J. Aleksejev, osutuvad nii küti häälejäljendused kui peibutuspillid omamoodi helilisteks püügiriistadeks - akustilisteks püünisteks ja lõksudeks. Sama oluline osa oli akustilisel kanalil ka omamoodi kodustamiskeele formeerimisel. Helidega mõjutamisel põhinevad põhjapõdrakasvatajate käsuhüüded, mis juhivad karja liikumisi ja psühholoogilist seisundit, üksiku looma ja terve karja rahustamine eriliste hüüete abil ning isegi spetsiaalsed laulukesed, mis on ette nähtud heliteraapiaks (et näiteks emasloom võtaks toidule orvuks jäänud vasika). Eriti peened häälelised mõjutamise vormid olid näiteks karja juhtimine helikontakti abil, aga ka erinevad käsud ja hüüded (tihti jäljenduslikku laadi), mida kasutati nt veoloomade juhtimisel (Aleksejev 1995: 33).

Ent loodushäälte imiteerimine ei piirdunud ainult utilitaarsete eesmärkidega. J. Šeikini (1983: 81-85) andmetel on näiteks udeheedel eriline vokaalliik diganaini, mis tähendab sõna-sõnalt 'tekitada heli või laulda, jäljendades looma- või linnuhäält' (sellise žanri avastas ta ka teistel tunguusi-mandžu rahvastel: negidaalidel dilgan, orokkidel dzildan, mandžudel dzilgan). See žanr sisaldab naturalistlikke (ikoonilisi) ja sümboolseid helijäljendusi.

Esimesed neist on originaali täpsed matkimised (karje, ulgumine, vilistamine jne), mõnede reprodutseerimiseks on loodud erilised pillid. Just neid loodushäälendeid kasutatakse jahil peibutamiseks, s.o utilitaarsetel eesmärkidel. Sellest tuleneb ka keeld esitada naturalistlikke loodushäälendeid väljaspool jahisituatsiooni, näiteks mängudes ja rituaalides. Erandiks olid vaid šamaanirituaalid, kus reaalsete loomakarjete võimalikult täpset matkimist kasutati hoopis signaalifunktsioonis (vastavate šamaanivaimudeabiliste kutsumiseks) või märkimaks nende "saabumist" šamaani kutsel.

Sümboolsed jäljendamised on J. Šeikini andmetel küll originaalisarnased, kuid erinevad sellest mõnevõrra, andes edasi vaid üldise helilise mulje. Neid on võimalik reprodutseerida kas harili$\mathrm{ku}$ kõneintonatsiooniga ( $\mathrm{nn}$ onomatopoeetilised sõnad, mis annavad foneetiliselt mulje edasi) või siis meloodiliselt intoneerides 


\section{Jelena Novik}

ja laiendada erilisteks loodushäälenditeks-lauludeks. Viimaseid esitatakse meelelahutuseks, kasutatakse mängudes (näiteks jäljendades metssiga ja karu) ja kombetalitustel, aga ka jututekstides, kus nad markeerivad tegelase otsest kõnet onomatopoeetilise refrääni või hüüdena. Teises artiklis märgib J. Šeikin, et loodushäälendid, mida folklooris kasutatakse, on akustilisest vaatevinklist nii helikõrguse kui ka rütmika poolest muudetud, need kõiguvad ikoonilisest täpsusest äratundmatute modifikatsioonideni, sõltuvalt kultuurilisest mõttest, mida nendesse imitatsioonidesse pannakse (Šeikin 1988: 16, 18).

Samasugune muutumine leiab aset ka tšuktšide (pitšjeinjen), korjakkide (karigjainjetõk) ja veel mitme Siberi rahva kuulsa kõrilaulmise sisse- ja väljahingamisel, andmaks edasi muljet põtrade möirgamisest, kajakate karjetest või helidest, mida teevad viigrid, morsad ja hülged (Vdovin 1973: 39; Žornitskaja 1983: 73). Dolgaanid nimetasid sellist matkimist, mis arenes ikoonilisest märgist sümboliks, seljaga laulmiseks. Selle esitamiseks oli vaja eriliste oskustega inimesi, sealjuures toovad lauljad (kui neid nii võib nimetada) esile kõrihelisid, mis meenutavad põdrapulli möiret (Popov 1937: 20). Jakuutia evengid kasutavad seevastu põtrade (engtevun) hääle matkimist nende ligimeelitamiseks kevadel, s.t säilinud on utilitaarne karjakasvatuse funktsioon (Šeikin 1988: 12).

Pole kahtlust, et muusikalise folkloori tekke (sh erinevate intoneerimistüüpide formeerimisel, mis on omased Siberi folkloorile) juures olid heliimitatsioonid märksa olulisemad kui matkimine keele formeerimisel. Muuseas, ülalmainitud onomatopoeetilised sõnad moodustavad üsnagi laialdase kihi soome-ugri, tunguusimandžu ja teiste Siberi rahvaste ühissõnavaras, ka jutustava folkloori kujundlikus süsteemis on need olulised.

Näiteks nanai juttudes kasutatakse palju onomatopoeetilisi sõnu kangelaste kõne edasiandmiseks. Ühel juhul matkivad need helisid (näiteks sõnad sikojakoja ganioki annavad tinglikult edasi nutuheli, kangelaste nuuksumist, tšekong aerude laksumist, tši-tši-tširulde tihase siutsumist), teistel juhtudel kujutavad aga liikumist (sõnapaar kumbiek kejuke annab edasi oma armsamat otsima mineva neiu kõikuvat kõnnakut). Need sõnad muudavad iga tegelase kuju konkreetseks, näitlikuks [---], kannavad kindlat kunstilist mõtet ja mängivad peale selle tähtsat osa laulude vormikujundusel, lõpetades kangelaste kõne iga fraasi (Bulgakova 1983: 4-5). 
Amuuri rahvaste keelte onomatopoeetiline sõnavara demonstreerib eredalt, kuidas kulgeb liikumine konkreetselt kontseptuaalsele: akustilisi iseloomustusi kasutatakse mitte ainult välisilme edastamiseks, vaid ka rahvaluuletegelase portreteerimiseks. Tema otseses kõnes on need tema nime analoogiks.

Kuid üldistus hääle ja heli põhjal võib olla veel sügavam: kuuldavaid objekte peetakse hinagmise ja hingega elusolenditeks, ${ }^{3}$ aga häält (meloodia, instrumentaalne pala) materiaalseks substantsiks või iseseisvaks tegelaseks.

Nii on eenetsitel ettekujutus, et mitte ainult igal inimesel, vaid ka loomal ja isegi esemel on oma laul (baree) (Šeikin 1996: 26). Selles mõttes on huvitav jukagiiride pulmaõnnistus, milles laulja pöördub kõigepealt noorpaari, seejärel selle paiga haldjate, lõpus aga kogu looduse kui isikupärase, elava ja heliseva poole. Kõik hä̈̈lekad õnnestumised, kõiksugu tiivulised häälitsejad, kõiksugu koputavad, sumisemad taimed, teile kõigile kingin rõõmu [---] (Kreinovitš 1972: 83).

Seega viib suulise kultuuri tingimustes heli semiotiseerimine selleni, et helide matkimine ja loodushääled semantiseeruvad ja hakkavad funktsioneerima, s.t neid hinnatakse ja osaliselt teadvustatakse kui 1) looduslikke objekte ja nende liigiliste erinevuste tunnuseid; 2) kui kontseptsiooni, mis tähistab elusolendit ja elu ning lõpuks 3) kui kavatsuse väljendust ja võimalust juhtida teise käitumist.

Seesama semiootiliste funktsioonide struktuur - denoteerida (tähistada), kontsepteerida (tähendada) ja reguleerida (väljendada) - rekonstrueeritakse ka inimhäälega seotud uskumuste jaoks.

Ülal oli juttu, et helilist koodi kasutatakse laialdaselt kirjeldamaks erinevusi looduses, kuid sama printsiipi kasutati ka eristamaks inimesi inimkollektiivis. Eeskätt puudutab see nn isiklikke laule. Täpsem oleks ehk rääkida isiklikest viisidest, mida on fikseeritud tšuktšidel, korjakkidel, kettidel, nganassaanidel ja teistel Siberi rahvastel.

See on eriline lüürikaliik, mida iseloomustab stabiilne meloodia, mis on laulu omaniku omalaadne leitmotiiv. Sellisele isiklikule motiivile, mis on enda loodud, saadud kingituseks vanematelt, päritud vms, improviseeriti sõnad vastavalt olukorrale, näiteks kurameerimise ajal. Sagedamini esitati selliseid laule küll mitte kuulajatele, vaid enda meeleheaks, näiteks õmblemise või mõne muu töö ajal. ${ }^{4}$ 
Nende lauluviiside üheks oluliseks jooneks on orienteerumine individuaalsele vokaalsele eneseväljendusele ja võõraste häältega sarnasuse vältimisele. Teisisõnu, nad funktsioneerivad kultuuris konkreetse isiku helilise autoportreena ja on tema vaimse kordumatuse ning individuaalsuse väljendamise vahendiks.

Etnoloogiakirjanduses on juba märgitud, et arhailine teadvus vaatleb inimese häält võrdväärsena selliste omadustega nagu nimi, kuju ja hing (Sagalajev \& Oktjabrskaja 1990: 145). Kui selle all mõista "indiviidi psühhosomaatilist terviklikkust", ${ }^{5}$ siis on isiklik laul vaieldamatult traditsioonilise ühiskonna inimeste eneseväljenduse vorm ja inimese ning tema isiksuse omamoodi muusikaline embleem.

Siit saab selgeks, miks suulistes kultuurides on isikliku lauluga seotud rida sümptomaatilisi keelde. Nii kaitsesid näiteks nganassaanid kiivalt lauluomandit. Arvati, et see meloodia moodustab samasuguse inimese omandi, nagu tema mõtted, hingamine, rõivad jne. Võorast viisi laulev inimene võis omanikult oodata karistust. Selline "osatamine" kutsus veel 1960. aastatel esile aktiivse protesti, eriti kui noored nganassaanid üritasid korrata vanakeste meloodiaid. See on seletatav arvamusega, et laulu kordaja võttis osa kõige salajasemast, inimesest endast: tema eneseväljendusest ja mõtetest. Võõrast motiivi korrates võib sinna sisse panna oma sisu, mitte ainult sõnad, vaid ka oma mõtted, muuta tähendusvarjundit jne. Suur tähtsus on ka sellel, et ei laulda "oma häälega”. See aga ajab mõtted segi ja mõjub kahjulikult õigele omanikule. See, kes kordab võõrast laulu, "varastab omaniku mõistust (korsa)" (Gratšova 1983: 56). Oma meloodia on loonud inimese mõtlemine ja see kuulub kokku tema sisemise olemusega. Kui teine inimene seda esitab, laulab või moonutab, "läheb" laul kui olend ilmaruumi [---] ega materialiseeru tahkes kehas ega skulptuuris, teda pole võimalik kinni hoida ega kinnistada. Võõra laulu lauljat nimetasid vanakesed täiesti õigustatult äärmiselt põlastusvä̈̈rseks olendiks, kõige madalamat sorti sõimunime "varas" kandjaks. Inimesele on võimalik kahju teha tema laulu kaudu (Gratšova 1983: 56).

Niisiis on G. Gratšova arvates tegu sellega, et lauluviis, "hääl" on indiviidi võõrandamatu osa, tema hing. Seepärast puudutatakse võõrast meloodiat esitades elusat ja häiritakse teda vajaduseta. Sellele võib lisada, et isiklike lauludega seotud ettekujutused on tingitud juba vaadeldud semiootilistest funktsioonidest: akustiliste signaalide, embleemide või leitmotiividena on need (käsikäes 
näiteks rõivastusega) indiviidi ja tema individuaalse staatuse (nime) väljendus. Märgi sisuks on erineva abstraktsiooniastmega tähendused alates konkreetsest emotsioonist kuni hingekontseptsioonini.

Selline tihe seos lauluviisi ja omaniku vahel on täheldatav ka tšuktšidel. Välitöödel Tšukotkal kuulsin järgmisest juhtumist. Kohaliku klubi aktivistid, keda kultuuriministeeriumi ametnikud olid ärgitanud rahvaluulet koguma ja propageerima, lindistasid tundras tšinitkin kulikuule ja asusid seejärel klubi valjuhääldi abil neid külas "propageerima". Näidete hulgas leidus ka ühe surnud vanamemme laul. Traditsioonikandjad, erinevalt kultuuritöötajatest, identifitseerisid laulu eksimatult: rabatuna pühaduse teotamisest ja hirmutatuna võimalikest tagajärgedest kogunesid nad klubi juurde ja nõudsid ülekande silmapilkset lõpetamist.

Selles, et suulise kultuuri kandjate mälu on kindel, et nad mäletavad kaua ja täpselt, kelle isiklikke ja ka teisi nende repertuaari kuuluvaid laule nad esitavad, on olnud välitöödel korduvalt võimalik veenduda. 1980. aasta ekspeditsioonil Jakuutias lindistasime kolleegidega endiselt šamaani abiliselt kuturuksuta N. Ivanovilt abivaimude väljakutsumist. Abivaimud kuulusid surnud šamaan Pavlovile, keda meie informant oli nooruses aidanud. Hommikul tuli meie juurde Pavlovi poeg, ise juba vanamees, ja ütles, et kuulis eile isa laule.

Analoogseid tähelepanekuid leidub ka etnoloogiakirjanduses, põhiliselt puudutab see šamaanilaulude laulmist. Tšuktšidel on igal šamaanil mitu isiklikku laulu, mida ümberkaudsed hästi teavad. Kui keegi mingil peol mõnda neist laulab, tunnevad kuulajad selle kohe ära ja ütlevad, et inimene laulis selle või tolle šamaani laulu (Bogoraz 1939: 120). Šamanistlike seansside ajal pidi selliste laulude esitamine kujutama šamaani surnud sugulaste "saabumist" tema abivaimude rolli täitma. Šamaaniriitusele kogunenud pealtvaatajad tundsid kergesti ära, kelle laulud need on. E. Prokofjeva tähelepaneku kohaselt tundsid loitsimisele (kamlanjele) kogunenud sölkupid sageli šamaani lauludes ära tema vanaisa laulud. Šamaanilaulude oskamist peeti šamaani küpsuse kriteeriumiks, tõendiks tema valmisolekust saada neid või teisi šamaanirüü atribuute (Prokofjeva 1949: 337).

Isiklike lauludega oli seotud veel üks tava: I. Bogdanovi (Brodski) andmetel saab inimene esimese oma laulu juba lapseeas kingituseks emalt või isalt. Täiskasvanuks saades loob ta oma laulu 


\section{Jelena Novik}

juba ise ja, tundes surma lähenevat, esitab aeg-ajalt oma matuselaulu - omamoodi reekviemi iseendale (Brodski 1976: 246-248). Sel juhul on tegemist isiklike laulude vahetusega üleminekul lapseeast täisikka ja vanadusse, s.t inimese sotsiaalse staatuse muutumisel. Nende laulude viisid on omamoodi ühiskondliku seisundi märk, olles justkui tema akustiliseks meetrikaks, passiks ehk isikutunnistuseks.

Isiklikud laulud on indiviidi sotsiaalse staatuse märgina seotud veel ühe olulise eripäraga: esitajad koostavad neid tavaliselt sugukonna, perekonna või territoriaalse rühma stilistilistele normidele toetudes (Šeikin 1996: 12), s.t need võisid olla n.-ö perekonna või "sissekirjutuse" muusikaliseks tähistuseks.

Märkides indiviidi sugukondlikku või perekondlikku kuuluvust, osutusid sugukonna või lokaalsed meloodiad ehk laulud teistega suhtlemisel omamoodi sümboliks.

Näiteks V. Tšernetsov teatab, et karupeietel, kus osalesid erinevate territoriaalsete rühmade liikmed, esitasid mansid erilisi laule ja pillilugusid, mis tähistasid kohta või sugukonda, kuhu need rühmad kuulusid (Tšernetsov 1971: 110). I. Gemujevi ja A. Sagalajevi materjalide põhjal kogunesid iga aasta augusti algul mansi külla Lombovoži Ljapini, Põhja-Sosva ja Obi piirkonna asunduste mehed, naised ja lapsed ning korraldasid nädala jooksul paadivõistlusi (mansi $k$ kasne hap). Iga asustus pani välja oma võistkonna (12 inimest) spetsiaalselt selleks puhuks valmistatud paadiga. Lisaks kümnele sõudjale, kes istusid paarikaupa ja sõudsid ühe aeruga, oli ahtris tüürimees ja paadininas muusik sangultapiga. Võistluse ajal mängis iga muusik oma rütmilist meloodiat, dikteerides sellega sõidutempot (Gemujev \& Sagalajev 1986: 85-87). Täpsemat teavet manside ja hantide pillimängust annab J. Šeikin. Tema andmetel esitas iga paadisõidust osavõttev muusik vastava lokaalse rühma tüüpmeloodiat, et aga võistluse marsruut kulges läbi pühapaikade, esitles iga paatkonna muusika erinevate külade elanikke jumalusele (Šeikin 1990: 8-9).

See arvamus on täiesti põhjendatud, sest Šeikin avastas (ning kirjeldas ja noodistas) mansi ja handi rahvamuusikute repertuaaris hulka pillilugusid, mille meloodia markeerib kindlat territoriaalset (lokaalset) rühma. Sellised on mansi Obi-äärsete neidude tantsuviis (As ati jikv tan), Jalpusi küla neidude tantsuviis (Jalpus agit jikv tan), Pastõri neidude viis (Pastõr agit tan), Tapisi meeste tantsuviis (Tapis hum tan). 
Sellist tüüpi sugukondlike ja perekondlike meloodiate kohta, millega pidudel võetakse vastu vastavate rühmade liikmeid, kirjutas V. Ivanov seoses kuulsa teatri- ja filmilavastaja Sergei Eisensteini töötamisega Wagneri "Valküüri" lavastuse kallal, et S. Eisenstein nägi neis analoogiat rahvushümnide ja fanfaarihelidega, mis annavad teada kõrget sotsiaalset päritolu külalise ilmumisest. Veelgi enam, tema arvates võivad selliseks analoogiks olla raadiojaamade kutsungid, mis esinevad kui indiviid küberneetilises mõttes, s.t suhtlemissüsteemi kuuluva keeruliselt organiseeritud süsteemina (Ivanov 1976: 90-91).

Viimane võrdlus tundub kõige õnnestunum, sest see toob esile veel ühe üliolulise omapära, mis on ilmnenud erinevate rahvaste kultussüsteemides. Obi-ugrilastel ilmneb see selles, et igal territoriaalsel rühmal olid nn kohalikud haldjad ehk kaitsevaimud ( upõhh), kes ühest küljest modelleerisid vastavat rühma, teisalt aga moodustasid ülemjumala Toorumi poegade ja lapselastena panteoni selle hierarhiliste jaotustega.

Etnomusikoloogidel ja etnoloogidel õnnestus lindistada kohalike haldjate meloodiaid. Ljapini-äärsed mansid mäletavad siiani viise, mis on pühendatud mõnele nende panteoni ja folkloori tegelasele. Nii lindistati viise, mis on pühendatud Hont-Toorumile, JibõOikale ja Paipõn-Oikale. Minevikus esitati neid sangultapil pühapaiku külastades. Meloodiad, mis olid nimetatud kaitsevaimude muusikalisteks portreedeks, pidid köitma viimaste tähelepanu. Sel viisil täitsid nad sama funktsiooni kui laulud-kutsungid (Gemujev \& Sagalajev 1986: 68).

Tundub aga, et märgiliste funktsioonide suhe on siin keerlisem. J. Gippiuse (1988) ja J. Šeikini (1990) materjalide põhjal mängiti sangultappi (sankvltap, sangultap) põhiliselt karupeietel. Nii lindistas J. Šeikin mansi pilliloo, mida informant G. Sainahhov nimetas sõjajumala viisiks (Hont-Torum oika tan) (Šeikin 1990: 10), keda austati ja peeti Ljapini jõel Ai-as-Toorumi pojaks ja Numi-Toorumi pojapojaks. Teine pala kandis nime "Tiivulise vanamehe viis" (Tovlen oika tan). Nimetatu oli Jarkini perekonna kaitsevaim, kelle pühapaik asub Obi ääres Ülem-Narõkarist ülesvoolu (Šeikin 1990: 14). Seda esitati karupeietel saatmaks tantsu, millega esitaja jäljendab tiibadega lehvitamist ja hiljem minemalendamist (Tšernetsov 1987: 232). J. Gippiuse tähelepaneku põhjal kehastab Pelõmi manside esivanema tantsuviis (Polum Torum tan) tema hinge, kuid kujutab muusikalistelt endast vastava rühma lokaalset pillilugu (Gippius 1988: 165). 
Niisiis võib obi-ugrilaste karupeietel hästi jälgida, kuidas "hinge hääl" (laul või instrumentaalpala) muutub esivanema-kaitsevaimu religioosse ilmutuse vormiks ja on tema ja ta elus järeltulijate vahelise kontakti saavutamise viisiks. Kusjuures sotsiaalsete rühmade klassifitseerimine ja jagamine sugukondlike (territoriaalsete) laulude järgi ei ole, nagu ülal märgitud, vastuolus ainulisuse, konkreetsuse ja individuaalsuse põhimõttega: sugukondlikud lauluviisid võivad üheaegselt edasi anda nii rühma kui ka selle rühma esivanema häält (niisiis on pupõh-oika konkreetse territoriaalse rühma esivanem või kaitsevaim, modelleerides teda personaalse koodiga, vrd ülaltooduga: V. Ivanov indiviidist selle sõna küberneetilises mõttes).

Peab lisama, et kõik laulud ja tantsud, mida esitatakse karupeietel, kantakse ette peietel austatava karu palge ees (kusjuures sõna otseses mõttes näo ees: karunahk pea ja käppadega asub keskel ja kõik toimub tema ees).

Selline vaatepunkt on traditsioonikandjate jaoks aktuaalne tänini: 1991. aasta augustis handi külas Kazõmis korraldatud visuaalse antropoloogia seminaril ütles üks osavõtja - võrdlemisi noor oma folkloori uurimisest innustatud hant - , et sooviks filmida karupeietel laulu, milles kirjeldatakse teed, mida mööda jõevaim Pelõm (Polum Oika, Polum-Torum, Topal-Oika) peole saabub. Kõiki laulus nimetatavaid kohti tundis ta ise ja kavatses nüüd käia seda teed videokaameraga. Ootamatult ta kükitas ja ütles, et seda laulu peab filmima nimelt sellest asendist, sest kõike, mida laulus kirjeldatakse, näeb ka karu ise.

Kui edaspidi kõrvutada seda fakti nn karulaulude esitamisega esimeses isikus, ei õnnestu seda seletada lihtsalt juhuse või kunstilise eripäraga. Karulaulud on sisult müüdid karu taevasest päritolust ja karu kohtumistest mineviku kuulsate küttidega, s.t neis on süžeeline organiseeritus, seal kirjeldatakse taevase tüli kõiki sündmusi ja karu laskumist maale karu enda vaatevinklist.

Vaatame nüüd Siberi jutustavat folkloori. Süžeeliselt organiseeritud tekstide analüüsil (näiteks lauldav kangelaslugu V. Žirmunski terminoloogia järgi) vaadeldakse harilikult vaid nende verbaalset külge. Tõsiasja, et neid laule lauldakse, vaadeldakse harilikult kunstilise iseärasusena, mis on seotud kas mnemotehnika ja vormi või erinevate folkloorsete uuendustega. Näib, et Siberi materjalis on arvukalt üleminekuvorme, milles tavandi religioosse ilmutuse seisund muutub sujuvalt folkloorseks esituseks. 
Siberi eepilist pärimust uurides on kasulik silmas pidada kogu hääle ja seda esindavate viisidega seotud ettekujutuste kompleksi. Neis avastatud semiootiliste funktsioonide realiseerimise vormid lubavad võib-olla paremini mõista egomorfismi või esimeses ja kolmandas isikus jutustamise tehnikat, mida on kasutatud peaaegu kõigis Siberi eepika liikides.

On teada, et paljusid eepilisi teoseid esitati selles piirkonnas laulu või ka retsitatiivi ja laulu segavormina, mis on seda tähelepanuväärsem, et sel juhul antakse lauluga edasi just nimelt tegelaste otsene kõne. Tavaliselt on sellistel monolooglauludel vormellik olemus, s.t nad kujutavad endast leitmotiive. Selliste personifitseeritud viiside - leitmotiivide - meloodilisele struktuurile annavad mõnikord tooni erilised laulu ülesvõtmissõnad-hüüded (kaasitused).

Nüüd selle võtte kasutamisest evengi nimngakanites. G. Vassiljevitš (1966: 13) märgib: Mõningatel juhtudel võib sätestada, et eellaulu läbiv püsisõna oli varem kangelase või tema sugukonna nimi, võib-olla koguni hõimu nimetus. Näiteks refrään orel-orel lähendab selle Oreli suguvõsale Amguuni jõe ääres, devedareko ja kidani või kedaikenen seostub 17. sajandil fikseeritud idaevengi Devedarski ja Kidarski hõimunimedega, kimo-kimo-kimoko Kima (evengi) ja Kimonko (udehee) sugukonnaga, lugu "Vaku-vaku" aga Nepi evengi Vakuvagiri suguharu nimega.

Eespool oli juba juttu, et šamaaniviisid tähistasid tihti suulise traditsiooni kandjate treenitud kõrvale selle esivanema häält, kellelt šamaan oli pärinud oma ande. B. Dobrovolski analüüsis Kodaktšoni nimngakani tegelaste monolooge ja näitas, et need laulud on mingiteks sugukondlikeks muusikalisteks hieroglüüfideks, mis on vaieldamatult muistset päritolu (Dobrovolski 1966: 385). Tõsi küll, tänapäeval lindistatud evengi keskmise maailma vägilasest jutustavates lugulauludes on sugulus- või rituaalne side kangelaste ja kuulajate vahelt peaaegu kadunud. Palade jaotus märgistab suuremaid tegelaskogumeid pigem vastavuses nende sotsiaalse staatuse kui sugukondliku kuuluvusega. Näiteks lugulaulus Kodaktšonist iseloomustab üks ja sama vormel: 1) vanemaid, kelle lapsed abielluvad; 2) sama suguharu mehi, keda seovad veresidemed, sh kangelast ja tema ratsut; 3) ja 4) erinevate sugukondade naiste teemasid ja 5) vaenlase teemat (Dobrovolski 1966: 385).

Sellise tendentsi arengut kinnitab ka hiljuti teostatud evengi lugulaulude detailne viisiuurimus (Eisenštadt \& Šeikin 1990: 
89-124): lauluviisid märgistavad tähtsamaid süeelisi olukordi, nende stilistika aga suhestub püsivate tegelasrühmadega. Veelgi selgemalt tuleb see printsiip ilmsiks jakuudi olonho puhul, kus tegelaste monoloogid lauldakse, laulude stiililine jaotus on aga seotud tegelaskujude jaotumisega ülemisse, keskmisse ja alumisse maailma (Rešetnikova 1993).

Veelgi selgemalt on jälgitav side jutustavate tekstide lauluvormis esitamise ning lahkunud esivanemate ja elavate põlvkonna vahelise ajalise distantsi ületamise püüe jälgitav ugri ja samojeedi ning saami traditsioonis. Siin on eriline suhtumine laulu koodi (ungari folkloristi E. Schmidti termin), mida kasutatakse kõige sakraalsete müütide ja mütoloogilise pärimuse esitamisel.

Näiteks saamid tõstsid oma folklooris terminoloogiliselt esile lovta müüdid, mis olid lauluvormis ja vastandusid proosapärimusele (mains). Viimaseid peeti kergeks žanriks, neid oli lubatud rääkida, kuidas kellelegi meeldis, samal ajal kui lovta esitamisel oli rahvalaulik iga sõna suhtes range. V. Tšarnoluski osundab seda eripära esile tuues näiteks ühe meisterliku jutuvestja ütlusele lovta kohta: Kaugest, ennemuistsest ajast muinasjutt [---]. Nende sõnadega, kuidas kord meie vanataadid on rääkinud, nende sõnadega tahaks öelda. Kuid rääkida võin ma ju ainult oma sõnadega. Ja need sõnad on minu sõnad, minu jutt, mitte aga esiisade täpsed sõnad. Nemad laulsid laulu, kõik sõnad olid kooskõlas. Minu sõnad aga sünnivad vaevaliselt. Räägin sulle kui muinasjuttu, kuid see ei ole muinasjutt, see on tõsilugu, meie vanaisade vanaisade lauldud lugu (Tšarnoluski 1962: 17-18). Siin käsitletakse laulu koodi ja selle kanoniseeritud vormi kui esiisade sõna, mis suudab kõige täpsemalt ja usutavamalt hoida ja edastada andmeid mütoloogilise mineviku sündmustest.

Termin ar tähistab hantidel mitte ainult 'laulma', 'laul', vaid sisaldab semantilise osana ka määratlust 'iidne', 'muistne', 'legendaarne'. N. Lukina andmetel nimetavad handid oma esivanemaid ar-jah (laulurahvas); ammu tehtud asja suhtes võisid nad kasutada vormelit teinud lauluinimene (Lukina 1990: 32). Võib oletada, et siin peetakse silmas neid, kellest lauldakse eepikas, ja on ilmekas, et müütiline aeg kandis mansidel nimetust erõk ijis, sõna-sõnalt 'laulude aeg' (Sokolova 1987: 124).

Veendumus, et mütoloogiline tekst on seotud esivanemaga, et need on "tema sõnad", on kõige tihedamini seotud just tema "häälega". Harvad on juhud, kui tekstis nimetatakse otseselt tegelase 
nimi - näiteks keti tekstid Dohhist lõppesid V. Anutšini sõnul (see väide on dokumentaalselt tõestamata) vormeliga: "Nii ütles Dohh."

Märgin, et Dohh on kahest sugukonnast (kentan) ühe esivanem ja iga selle sugukonna kett teadis suurepäraselt oma põlvnemist endast temani. Kas selline teadmine vastab tõele, on iseasi. Genealoogilised uurimused kinnitavad, et viie-kuue põlve ulatuses on pärimus absoluutselt usaldusväärne. Dohhist on hulganisti pärimust, milles kõnealune vormel puudub, mis mõistagi ei vähenda kuidagi Dohhi kuju ega nende tekstide autoriteetsust. Lõpuks, kuigi Dohh ei ole seotud tavanditseremooniatega, s.t ei kuulu otseselt kaitsehaldjate panteoni, hõlvab ta keti usundisüsteemis täiesti erilise koha, sest pärimuse kohaselt on määratud, et ta ärkab tulevikus ellu. Seepärast ei ole üllatav, et tekste, mis sisaldavad vormelit "nii ütles Dohh", võidi vastu võtta kui tema otsest manitsust.

Ainud, kes elavad Siberi äärealal, kuid kellel A. Spevakovski viimaste uurimuste kohaselt olid üsna ammu sidemed tunguusimandžu ja võib-olla ka uurali keelkonna rahvastega (Spevakovski 1988), nimetasid seda tüüpi didaktilisi jutustusi upaskumadeks. Jumalate päritolust, erinevatest uskumustest ja tavadest kõnelevaid lugusid jutustatakse esimeses isikus ja alles lõpus öeldakse autori nimi. Jutuvestja sõnutsi leidub ainude seas siiani perekondi, kes peavad end tema jutustatud upaskuma kangelaste järglasteks ja usuvad end põlvnevat selles mainitavatelt tähtedelt (Nevski 1972: 20). Teine ainu folklooriliik on oina, millest suur osa arvatakse pärinevat Aeoinakamuilt endalt - ainu kultuuriheeroselt ja valgustajalt, kes pani aluse kõikidele ainu uskumustele ja kogu elukorraldusele. Meenutagem siinjuures, et peaaegu kõik ainu folkloori jutustavad žanrid esitatakse esimeses isikus, kusjuures "hääl" antakse edasi refräänsõnade abil analoogiliselt ülalkirjeldatud evengi lauldude refräänidele, millest suurem osa on loodushäälendid või onomatopoeetilised sõnad.

Tulgem siiski tagasi Siberi põhialadele. Ka siin kohtab üsna tihti eepilisi vorme, mis on tervikuna üles ehitatud esimeses isikus jutustamisele. Lisaks juba mainitud karupeielauludele, mis räägivad taevase jumala Toorumi poja (või tütre) karu kujul maa peale laskumisest, esitatakse ka paljud handi kangelaslood vägilastest (keda samuti peetakse Toorumi lasteks) esimeses isikus. Neenetsitelt on fikseeritud koguni kolm eepilist žanri, mida esitatakse esimeses isikus: südbabts, jarabts ja hõnabts. Viimastest saadi teada üsna hiljuti J. Puškarjova kirjutisest (ilmumas). 
Tekib mõnevõrra veider situatsioon: kangelane justkui tõrjub eepika laulja kuju kõrvale, ta nagu näeb, kuuleb ja jälgib temaga toimuvaid sündmusi ning räägib neist jutustaja suu kaudu.

Seejuures tulevad ilmsiks hämmastavad detailid: kui süžee käigus kangelane-jutuvestja ei näe seda, kelle otsest kõnet ta esitab, lisab ta tavaliselt spetsiaalsed selgitavad märkused, nagu "näib", "ma arvan, et keegi ütles", "kellegi hääl ütles" jne.

Selline jutustuse klammerdumine tegelase vaatepunkti neenetsi eepikas (vrd imemuinasjutu kangelaskesksuse ja täiendava jaotuse seost) viib selleni, et teksti varieerimine võib kaasa tuua kangelase ja jutuvestja vaheldumise. Nii näiteks avaldas Z. Kuprijanova mitu varianti eepilisest laulust (südbabts) "Jabta Salja peremehe poeg”, mis jutustab poisist, kes jäi ellu pärast hõimutülisid. Ühes loos jutustatakse sellest tema õe vaatepunktist, teises vada südbabtsi ("sõna-laulu") vaatepunktist ja lõpuks kangelase enda vaatepunktist (Kuprijanova 1965).

Arhailised traditsioonid püüavad hämmastava järjekindlusega ühel või teisel viisil ära märkida isikut, kes seisab teksti taga. Laul või kõne on eepilise jutustuse tegelase hääl, mis kaebleb, väljendab pahameelt, valmistub võitluseks, samaaegselt eksisteerib see väljaütlemise hetkel sellega sünkroonselt, siin ja praegu.

Kui jutustajaks ei ole sündmustest osavõtja ise (kangelane või mõni teine tegelane), tekib tema ja jutustaja vahele kolmas tegelane - tõlkija-vahendaja. Tema ilmumist on võimalik seostada sellega, et suulisel jutustamisel kõlab ka jutustaja sõna, seda on omakorda võimalik vastu võtta kui häält. Nimelt tekib sel juhul eriline tegelane, kes on eriti selgelt esindatud uurali folklooris. Nii näiteks on neenetsite teose koestikus esindatud loominguline "sõna-jutuvestja" või "sõna-laul” (südbabts, mõniko, lahanako, hõnabts), kes kas laskub suitsuavast kotta, kus elavad kangelased, ja räägib, mis seal sünnib, või kandub tuulega kangelastele järel, lendab vaenlaste sekka jne. Analoogne tegelane, kes liigub paigast paika ja kelle nimel tehakse sündmuskohtast omamoodi "reportaaž", esineb ka nganassaani, eenetsi ja sölkupi folklooris (djöre - 'teade-sõna').

Eeltoodud vaatlused selgitavad, miks paljudes traditsioonides arvatakse, et laulja-jutuvestja "kutse" elustab eepilise kangelase kas autori, valdaja või isegi demiurgina, kes sõna otseses mõttes usutakse olevat korda saatnud kõik, millest eepos jutustab. Ta annab väljavalitule võimaluse ja ühtlasi kohustuse laulda iseendast. 
On võimalik, et just nimelt ettekujutused häälest kui ühe või teise isiku kehastusest on sünnitanud ka ettekujutused sellest, et folkloorse narratiivi esitus on ekvivalentne rituaaliga, s.t võimaldab luua vahetu kontakti üleloomuliku maailmaga. Väliselt adresseerimata, sh süžeeliselt organiseeritud tekst (erinevalt rituaalitekstidest, milles alati pöördutakse konkreetse kaitsevaimu poole) on kuuldeline. Teisisõnu, kõlaline reaalsus kindlustab nii sündmuste kui nende tegelaste "kohaloleku" ja muudab kõik, millest jutustaja räägib, reaalseks ja usaldusväärseks.

Seejuures tekib kuulajate ja jutustuse sündmuste vahel iselaadne osaluse ja kaastegevuse suhe. Esitan siinkohal fragmendi hea handi folkloori tundja E. Schmidti tähelepanekutest eepiliste laulude esitamise kohta: Sõnaline tegevus lahustab endas reaalsuse peaaegu täielikult, mille tulemusena tekib mulje, justkui muutuks laulja tegelaskujuks, kelle nimel ta laulab (täpsemalt: justkui see siseneks temasse). Tõenäoliselt tuleneb siit ka esimeses isikus laulmise tava. Üheaegselt tekib tunne, justkui toimuksid ammumöödunud sündmused uuesti, laulja viib kuulajad möödunud aegadesse, taasluues need oma lauluga. Pikaajaline laulmine lülitab nii laulja kui ka publiku reaalsusest välja. Ärgates tunnevad nad, justkui oleksid nad ise ja kogu ilmakorraldus uuesti sündinud, s.t leiab aset midagi katarsiselaadset (osundatud: Lukina 1990: 38).

Niisugune on häälel põhinev efekt suulises traditsioonis loob ilmutuse (mitte ainult haldjatest ja jumalustest, vaid ka minevikust), tugeva (lausa vere-)sideme nendega, omamoodi reinkarnatsiooni, müüdi tagasituleku (vrd M. Eliade).

Tõlkinud Merle Puidak

Tõlgitud teosest Novik, Jelena 1999. Semiotitšeskije funktsii golosa v folklore i verovanijahh narodov Sibiri. Lidova, N. \& Nikulin, N. (toim). Folklor $i$ mifologija Vostoka $v$ sravnitelno-tipologitšeskom osveštšenii. Moskva, lk 217-235.

\section{Kommentaarid}

${ }^{1}$ Tuletan meelde, et sümbolistlikus interaktsionismis mõeldakse žesti all mitte lihtsalt mingisugust kehaliigutust, vaid mis tahes vastuvõetavat heli või liigutust, mis on inimese siseelamuse näitajaks [---]. Liigutused ja helid saavad žestideks vaid sotsiaalses kontekstis, kui need on inimese kavatsuste näitajateks ja annavad sel viisil teistele vastavateks reaktsioonideks mingisugusegi aluse (Šibutani 1969: 122). 


\section{Jelena Novik}

${ }^{2}$ Mongolid nimetasidki neid neljasilmseteks.

${ }^{3}$ Vt J. Aleksejenko analüüsitud keti, dolgaani, jakuudi ja idahandi sõnu juuremorfeemiga $i l ' / i r$. Need sõnad moodustavad tähenduste kompleksi, mis on seotud laulmise, hingamise ja maise eluga (Aleksejenko 1984: 67-73).

${ }^{4}$ Nagu märkis üks naisinformant, võib ilus ornament õnnestuda vaid sel juhul, kui ta laulab selle tegemise ajal oma laulu.

${ }^{5}$ Vrd: polnud inimolendit, kes ei tunneks ainult oma keha, vaid samaaegselt ka oma vaimse ja kehalise individuaalsuse ühtsust (Moss 1996: 266). Vrd ka mina-kontseptsiooni mõiste sotsiaalpsühholoogias.

\section{Kasutatud kirjandus}

Aleksejenko, J. 1984. Etnokulturnõje aspektõ izutšenija šamanstva u ketov. Etnokulturnõje kontaktõ narodov Sibiri. Leningrad.

Aleksejev, J. 1995. Pragmatišeskoje, igrovoje, ritualnoje v zvukopodra $\square$ anijahh narodov Severa Sibiri. Golos i ritual. Materialy konferentsii. Moskva: Folklornaja komissija Sojuza kompozitorov Rossii. Gossudarstvennõi institut iskusstvoznanija, lk 33-35.

Bogoraz, V.1939. Třukši II. Leningrad.

Brodski, I. 1976. K izutšeniju muzõki narodov Severa RSFSR. Traditsionnoje i sovremennoje narodnoje muzõkalnoje iskusstvo. Sbornik trudov Gossudarstvennogo Myzõkalno-Pedagogitšeskogo Insituta imeni Gnessinõhh 29. Moskva.

Bulgakova, T. 1983 (koost). Ot sostavitelja. Nanaiskije napevõ. Habarovsk. Dobrovolski, B. 1966. Napevõ skazanija o Kodaktšone. G. Vassiljevitš (koost). Istoritšeskii folklor evenkov. Skazanija i predanija. Moskva \& Leningrad.

Eisenštadt, A. \& Šeikin, J. 1990. Muzõka evenkiiskihh skazanii. Evenkiiskije geroitšeskije skazanija. Pamjatniki folklora narodov Sibiri i Dalnego Vostoka. Novosibirsk.

Gemujev, I. \& Sagalajev, A. 1986. Religija naroda mansi. Kultovõje mesta XIX - natšala XX v. Novosibirsk.

Gippius, J. 1988. Ritualnõje instrumentalnõje naigrõši Medvežego prazdnika obskihh ugrov. Narodnõje muzõkalnõje instrumentõ $i$ instrumentalnaja muzõka II. Moskva.

Gratšova, G. 1983. Traditsionnoje mirovozzrenije ohhotnikov Taimõra (na materialahh nganassan XIX - natšala XX v.). Leningrad.

Hudjakov, I. 1969. Kratkoje opisanije Verhojanskogo okruga. Leningrad.

Ivanov, V. 1976. Otšerki po istorii semiotiki v SSSR. Moskva. 
Kossarev, M. 1984. Zapadnaja Sibir v drevnosti. Moskva.

Kreinovitš, J. 1972. Iz žizni tundrennõhh jukagirov na rubeže XIX i XX vv. Stranõ i narodõ Vostoka 13. Moskva.

Kreinovitš, J. 1973. Nivhgu. Zagadotšnõje obitateli Sahhalina i Amura. Moskva.

Kuprijanova, Z. 1965 (koost). Epitšeskije pesni nentsev. Moskva.

Lukina, N. 1990 (koost). Predislovie. Mifõ, predanija, skazki hantov $i$ mansi. Moskva.

Moss, M. 1996. Obtšestva. Obmen. Litšnost. Moskva.

Nevski, N. 1972. Ainskii folklor. Moskva.

Popov, A. 1937. O žizni i ustno-narodnom tvortšestve dolgan. Dolganskii folklor. Leningrad.

Popov, A. 1949. Materialõ po religii jakutov b. Viljuiskogo okruga. Sbornik muzeja antropologii i etnografii 11. Moskva \& Leningrad.

Popova 1981. Evenõ Magadanskoi oblasti. Moskva.

Prokofjeva J. 1949. Kostjum selkupskogo (ostjako-samoedskogo) šamana. Sbornik muzeja antropologii i etnografii 11 Moskva \& Leningrad.

Rešetnikova, A. 1993. Muzõka jakutskihh olonho. Jakutskii geroitšeskii epos "Kõõs Debilije”. 1993.

Sagalajev, A. \& Oktjabrskaja I. 1990. Traditsionnoje mirovozzrenije tjurkov Južnoi Sibiri. Znak i ritual. Novosibirsk.

Sokolova, Z. 1987. K proishoždeniju obskihh ugrov i ihh fratrii (po dannõm folklora). Traditsionnõje verovanija i bõt narodov Sibiri. Novosibirsk.

Spevakovski, A. 1988. Duhhi, oborotni, demonõ i božestva ainov. Moskva. Šeikin, J. 1983. Dopessennoje i pessennoje v folklore ude. Narodnaja pesnja. Problemõ izutšenija. Leningrad.

Šeikin, J. 1988. Aktualnõje problemõ muzõkalnoi etnografii Severnoi Azii (vmesto predislovija). Muzõkalnaja etnografija Severnoi Azii 10. Novosibirsk. Šeikin, J. 1990 (koost). Instrumentalnaja muzõka Jugrõ. Novosibirsk. Šeikin, J. 1996. Muzõkalnaja kultura narodov Severnoi Azii. Jakutsk. Šibutani, T. 1969. Sotsialnaja psihhologija. Moskva.

Žornitskaja, M. 1983. Narodnoje horeografitšeskoje iskusstvo korennogo naselenija Severo-Vostoka Sibiri. Moskva.

Tsintsius, V. 1971. Vozzrenija negidaltsev, svjazannõje s ohhotnitšim promõslom. Religioznõje predstavlenija i obrjadõ narodov Sibiri v XIX-natšale $X X$ veka. Leningrad. 
Jelena Novik

Tšarnoluski, V. 1962. O saamahh i ihh skazkahh. Saamskije skazki. Moskva.

Tšernetsov, V. 1971. Naskalnõje izobraženija Urala. Svod arheologitšeskihh istotšnikov V: 4-12 (2). Moskva.

Tšernetsov, V. 1987. Istotšniki o etnografii Zapadnoi Sibiri. Tomsk.

Tšistov, K. 1975. Spetsifika folklora v svete teorii informatsii. Tipologitšeskije issledovanija po folkloru. Sbornik statei pamjati V. J. Proppa (18951970). Moskva.

Vassiljevitš, G. 1966 (tõlk ja komment). Vvedenije. Istoritšeskii folklor evenkov. Skazanija i predanija. Zapiss tekstov. Moskva \& Leningrad.

Vdovin, I. 1973. Otšerki etnitšeskoi istorii korjakov. Leningrad. 